\title{
THE USE OF COOPERATIVE LEARNING MODEL NUMBERED HEADS TOGETHER AND REALISTIC MATHEMATICS EDUCATION IN TEACHING MATHEMATICS
}

\author{
Ismi Widyaningrum \\ Sekolah Tinggi Keguruan dan IImu Pendidikan Syekh Manshur \\ Ponsel : 087732180988 \\ Surel: ismiw3009@gmail.com
}

\begin{abstract}
The purpose of this study was to determine the effectiveness of cooperative learning model numbered heads together and realistic mathematics education. This type of research was a Classroom Action Research. These activities were conducted in two cycles. At first cycle, learning was carried out using NHT learning model and realistic mathematics education. Then the second cycle was carried out to fix anything that wasn't right. The results of this study were increasing the percentage of students learning, from 34,5\% in Pre Cycle, to $75,86 \%$ at the end of Cycle I, and became $93,1 \%$ at the end of Cycle II. Another improvement occurred in the activities of students and teachers. All of these improvements are certainly due to the presence of improvements during the learning process carried out by teachers and researcher over the last two cycles. The conclusion of this study is that cooperative learning with Numbered Heads Together Model and Realistic Mathematics Education can improve learning achievement in teaching mathematics.
\end{abstract}

Keywords: mathematics, NHT model, realistic mathematics education

\section{PENDAHULUAN}

Matematika merupakan mata pelajaran yang perlu diberikan kepada semua siswa dengan tujuan untuk membekali kemampuan berpikir logis, analitis, sistematis, kritis, dan kreatif, serta kemampuan bekerjasama (Depdiknas, 2007). Menurut teori belajar kontruktivisme, siswa harus membangun sendiri pengetahuan di dalam benaknya berdasarkan pengalaman-pengalaman belajar yang telah mereka miliki, sedangkan guru hanya bertindak sebagai fasilitator yang membantu siswa dalam mengkontruksi pemahamannya sehingga mampu memecahkan suatu permasalahan dalam pembelajaran.

Berdasarkan penelitian Depdiknas (2007) menunjukan bahwa masih banyak permasalahan pelaksanaan standar isi mata pelajaran Matematika. Pembelajaran yang dilakukan guru kurang kreatif, lebih banyak menggunakan metode ceramah dan kurang mengoptimalkan media pembelajaran. Dengan demikian, siswa kurang aktif dan kurang kreatif dalam pembelajaran.

$$
\text { Kendala dalam proses }
$$

pembelajaran di sekolah tersebut juga dihadapi oleh para guru di SD Negeri Kiarajangkung ketika melaksanakan 
pembelajaran matematika. Kendala yang dihadapi adalah minat belajar dan aktifitas siswa dalam pembelajaran matematika masih sangat kurang sehingga hasil belajar juga sangat rendah. Hal itu disebabkan karena guru mengajar sangat monoton, kurang menarik, siswa kurang aktif, Kegiatan belajar mengajar hanya menggunakan ceramah. Hasil belajar matematika yang sangat rendah merupakan suatu permasalahan yang harus segera diatasi. Untuk mengatasi masalah tersebut guru harus menciptakan suasana pembelajaran yang menyenangkan. Pengelolaan kelas yang baik dalam pembelajaran maka prosen pembelajaran aan berlangsung secara efektif dan afisien sehingga hasil belajar yang akan diinginkan akan tercapai. Kegiatan pembelajaran yang menyenangkan dapat tercipta bila guru menggunakan metode yang bervariasi, serta menggunakan pendekatan pembelajaran yang tepat. Dengan demikian, siswa akan merasa tertarik mempelajari matematika, mencoba dan membuktikan sendiri, sehingga akan memperkuat kemampuan kognitifnya. Selain itu, pembelajaran menjadi lebih bermakna dan tujuan pembelajaran matematika pada siswa SD dapat tercapai.

Berdasarkan data pencapaian hasil belajar siswa dari evaluasi pelajaran matematika siswa kelas IV SD $\mathrm{N}$ Kiarajangkung tahun ajaran 2019/2020, Kecamatan Cibitung, Kabupaten Pandeglang, diperoleh nilai terendah 15 , nilai tertinggi 95 dan nilai rata-ratarata 54,65. Dengan hasil refleksi awal, maka siswa kelas IV SD $\mathrm{N}$ Kiarajangkung dalam pelaksanaan pembelajaran matematika hanya mampu menyerap 34,48\%. Hal ini ditunjukkan dari 29 siswa yang mencapai Kriteria Ketuntasan Minimal (KKM) hanya 10 siswa, sedangkan 19 siswa lainnya $(65,5 \%)$ memperoleh nilai di bawah KKM.

Berdasarkan diskusi peneliti dengan guru kelas IV, untuk memecahkan masalah dan memperbaiki proses pembelajaran tersebut, maka peneliti beserta guru kelas IV menetapkan alternatif tindakan yang dapat diambil, yaitu pemilihan model pembelajaran dengan pendekatan yang tepat. Adapun model pembelajaran yang diterapkan yaitu model pembelajaran kooperatif learning. Model pembelajaran kooperatif merupakan strategi belajar dengan sejumlah siswa sebagai kelompok kecil yang tingkat kemampuannya berbeda. Dalam menyelesaikan tugas kelompoknya, setiap siswa anggota kelompok harus saling bekerja sama dan saling 
membantu untuk memahami materi pelajaran (Suratmin, 2020: 3).

Model pembelajaran Numbered Heads Together (NHT) atau penomoran berpikir bersama merupakan jenis pembelajaran kooperatif dengan langkah sebagai berikut, membagi kelas menjadi 5 kelompok, dengan setiap kelompok mendapatkan nama dan setiap anggota kelompok mendapatkan nama dan setiap anggota kelompok mendapatkan nomor identitas kemudian melakukan diskusi, setelah diskusi selesai, guru memanggil nomor siswa secara acak untuk mempresentasikan hasil diskusi kelompoknya. Peneliti memilih model pembelajaran NHT karena memiliki keunggulan, diantaranya pemahaman yang lebih mendalam, nilai-nilai kerjasama antar siswa lebih teruji, dan hasil belajar lebih tinggi. Model pembelajaran NHT sangat menyenangkan bagi siswa sehingga hasil belajar siswa meningkat dan melampaui target yang telah ditetapkan.

Pada penelitian ini peneliti memadukan model pembelajaran NHT dengan pendekatan matematika realistik. Pendekatan matematika realistik merupakan pendekatan yang menghadirkan masalah yang konteks dengan kehidupan siswa, sehingga siswa akan mudah untuk memahami materi matematika yang diajarkan oleh guru, siswa juga tertarik karena materi yang diajarkan berkaitan dengan kehidupan mereka, sehingga pada akhirnya kualitas pembelajaran matematika akan meningkat.

Perpaduan antara model pembelajaran NHT dengan pendekatan matematika realistik diharapkan dapat mengatasi permasalahan yang terjadi dalam pembelajaran matematika di kelas IV SD Negeri Kiarajangkung. Dengan perpaduan antara model pembelajaran NHT dengan pendekatan matematika realistik ini diharapkan dapat meningkatkan efektivitas keterampilan guru dalam mengelola pembelajaran, dan meningkatkan aktivitas serta hasil belajar siswa.

Penelitian yang berkaitan dengan model pembelajaran kooperatif NHT telah beberapa kali dilaksanakan, begitu juga penelitian dengan menggunakan pendekatan matematika realistik. Akan tetapi dari beberapa penelitian tersebut memiliki beberapa perbedaan pada masing-masing hasil penelitian, objek penelitian maupun kesimpulan yang diperoleh. Dalam penelitian ini, peneliti memadukan antara model pembelajaran kooperatif NHT dan pendekatan matematika realistik. Penelitian sebelumnya yang menggunakan perpaduan antara model pembelajaran kooperatif NHT dan 
pendekatan matematika realistik yaitu pada penelitian yang dilakukan oleh Jannah (2013) dengan judul "Eksperimentasi Model Pembelajaran Kooperatif Tipe Structured Number Heads (SNH) dan Numbered Heads Together (NHT) dengan Pendekatan Matematika Realistik pada Prestasi Belajar Matematika Ditinjau dari Kemandirian Belajar Siswa Kelas VII SMP Negeri di Kota Mataram Tahun Pelajaran 2012/2013." Penelitian tersebut meninjau dari segi kemandirian belajar siswa, sedangkan pada penelitian ini, peneliti meninjau dari keterampilan guru, aktivitas, serta hasil belajar siswa.

Berdasarkan uraian tersebut, peneliti dapat merumuskan permasalahan sebagai berikut: bagaimana efektivitas perpaduan antara model pembelajaran NHT dengan pendekatan matematika realistik dalam kualitas pembelajaran matematika siswa SD Negeri Kiarajangkung Tahun pelajaran 2019/2020". Tujuan penelitian ini adalah untuk mengetahui efektivitas pembelajaran matematika dengan menerapkan perpaduan antara model pembelajaran NHT dengan pendekatan matematika realistik pada siswa kelas IV di SD Negeri Kiarajangkung tahun pelajaran 2019/2020. Pada penelitian ini, hasil belajar matematika dibatasi pada materi operasi hitung bilangan.

\section{KAJIAN TEORITIK}

Pendidikan merupakan sebuah upaya yang berlandaskan peradaban untuk menuwujudkan kehidupan manusia yang mulia dan bermanfaat (Imtihanudin, 2021 : 5). Paradigma pendidikan di Indonesia yaitu mengacu pada teori kontruktivisme sebagai landasan pembelajaran kooperatif yang mendorong dan menghargai usaha belajar siswa. Definisi belajar menurut teori kontruktivisme yang lebih mengutamakan, menekankan dan terpusat pada keaktifan siswa diungkapkan oleh beberapa ahli. Menurut Uno (2012: 15), belajar adalah pemerolehan pengalaman baru oleh seseorang dalam bentuk interaksi belajar terhadap suatu objek yang ada dalam lingkungan. Kemudian menurut Linda (2020: 94), belajar adalah perubahan perilaku sebagai akibat dari melakukannya, hal ini mencakup mencari tahu sendiri, memberikan contoh-contoh, melatih keterampilanketerampilan, dan mengerjakan tugastugas berdasarkan pengetahuan yang dimiliki. Berdasarkan beberapa pendapat para ahli di atas, penulis memperoleh kesimpulan bahwa belajar adalah proses berkembangnya pengetahuan dan keterampilan seseorang dari pengetahuan dan 
keterampilan yang dimiliki sebelumnya, sehingga terjadi perubahan potensi pada diri orang tersebut.

Dibutuhkan suatu cara agar proses pembelajaran menjadi menarik dan tidak membosankan, yaitu salah satunya dengan menggunakan model pembelajaran. Model pembelajaran pada penelitian ini memadukan antara model pembelajaran kooperatif NHT dengan pendekatan matematika realistik.

Menurut Shoimin (2014: 108), model pembelajaran NHT merupakan suatu model pembelajaran berkelompok yang setiap anggota kelompoknya bertanggung jawab atas tugas kelompoknya, sehingga tidak ada pemisahan antara siswa yang satu dengan siswa yang lain dalam satu kelompok untuk saling memberi dan menerima antara satu dengan yang lainnya. Model pembelajaran NHT adalah suatu model pembelajaran yang lebih mengedepankan kepada aktivitas siswa dalam mencari, mengolah, dan melaporkan informasi dari berbagai sumber yang akhirnya dipresentasikan di depan kelas (Fathurrohman, 2015: 82). Berdasarkan pendapat beberapa ahli di atas, maka dapat disimpulkan bahwa model pembelajaran NHT merupakan suatu model pemeblajaran yang lebih mengutamakan kepada aktivitas siswa dalam mencari, mengolah dan melaporkan informasi dari berbagai sumber yang pada akhirnya dipresentasikan di depan kelas.

Pendekatan matematika realistik adalah prosedur atau cara yang digunakan guru untuk menyampaikan bahan pembelajaran matematika agar siswa memperoleh sejumlah kompetensi yang diharapkan (Windayana et al, 2005 :22). Menurut Hadi (2005: 52), pembelajaran matematika dengan pendekatan matematika realistik menjadikan pelajaran matematika lebih bermakna bagi siswa, karena dibimbing untuk menemukan konsep matematika dengan usaha mereka sendiri.

Pembelajaran dengan model NHT dengan pendekatan matematika realistik mempunyai keunggulan, yaitu jawaban dari hasil diskusi dan pertanyaan yang disampaikan dapat diketahui oleh setiap anggota kelompok, setiap anggota kelompok mempunyai kemampuan dan tanggung jawab yang sama untuk mencoba menjawab pertanyaan, dan hasil diskusi atau jawaban yang diperoleh lebih akurat karena didiskusikan 4-5 siswa. Selain keunggulan, model pembelajaran kooperatif NHT dengan pendekatan matematika realistik juga memiliki kelemahan, yaitu tidak semua anggota kelompok dipanggil oleh guru 
atau tidak semua anggota kelompok mempunyai kesempatan untuk mempresentasikan hasil diskusinya di depan kelas (Jannah, 2013: 28).

\section{METODE PENELITIAN}

Penelitian ini merupakan Penelitian Tindakan Kelas (PTK). PTK merupakan suatu pencermatan terhadap kegiatan yang sengaja dimunculkan, dan terjadi dalam sebuah kelas (Arikunto, 2010). Penelitian ini dilaksanakan di SD Negeri Kiarajangkung, Kecamatan Cibitung, Kabupaten Pandeglang. Subjek penelitian adalah siswa kelas IV sebanyak 29 siswa yang terdiri dari 19 siswa laki-laki dan 10 siswa perempuan.

Penelitian ini dilaksanakan dengan melaksanakan perencanaan yang telah dibuat sebelumnya yakni melaksanakan pembelajaran dengan model pembelajaran NHT dipadukan dengan pendekatan matematika realistik. Pelaksanaan tindakan penelitian ini direncanakan dalam dua siklus. Siklus I dilaksanakan pembelajaran dengan model perpaduan pembelajaran NHT dan matematika realistik. Selanjutnya siklus II dilaksanakan untuk memperbaiki segala sesuatu yang belum baik.

Subyek penelitian ini adalah guru dan siswa kelas IV SD Negeri Kiarajangkung, melalui hasil pengamatan, hasil refleksi, dan hasil tes. Jenis data dalam penelitian ini adalah data kuantitatif dan data kualitatif.

\section{HASIL DAN PEMBAHASAN}

Hasil observasi aktivitas guru pada pembelajaran

matematika menggunakan perpaduan model pembelajaran NHT dan pendekatan matematika realistik diperoleh bahwa siklus I ke siklus II mengalami peningkatan. Secara lebih jelas, peningkatan tersebut dapat dilihat pada Tabel 1 berikut ini.

\section{Tabel 1. Peningkatan Aktivitas Guru}

\begin{tabular}{l|c|c}
\hline \multicolumn{1}{c|}{ Indikator Aktivitas Guru } & \multicolumn{2}{c}{ Perolehan Skor } \\
\cline { 2 - 3 } & Siklus I & Siklus II \\
\hline Penyiapan materi ajar oleh guru & 4 & 4 \\
\hline Pembelajaran dimulai oleh guru & 2 & 3 \\
\hline Kemampuan guru dalam penyampaian materi & 2 & 4 \\
\hline $\begin{array}{l}\text { Pengajuan masalah dengan penyelesaian menggunakan } \\
\text { model pembelajaran NHT dan pendekatan matematika } \\
\text { realistik }\end{array}$ & 3 & \\
\hline $\begin{array}{l}\text { Penjelasan mengenai jalannya diskusi kelompok dalam } \\
\text { permainan menggunakan media kartu soal }\end{array}$ & 2 & 3 \\
\hline $\begin{array}{l}\text { Penjelasan kepada siswa mengenai penyajian hasil diskusi } \\
\text { dalam pemecahan masalah }\end{array}$ & 3 & 4 \\
\hline Penyampaian pertanyaan kepada siswa & 3 & 3 \\
\hline Penjelasan materi kembali sebagai penguatan & 2 & 3 \\
\hline Tindak lanjut dan motivasi untuk mengakhiri proses & 4 & 4 \\
\hline
\end{tabular}




\begin{tabular}{l|c|c}
\hline pembelajaran & & \\
\hline Jumlah Perolehan Skor & 25 & 30 \\
\hline Kategori & Baik & Baik \\
\hline
\end{tabular}

Klasifikasi kategori nilai klasikal untuk lembar pengamatan aktivitas guru yaitu perolehan $29,5 \leq$ skor $\leq 36$ merupakan kategori sangat baik, 22,5 $\leq$ skor $\leq 29,5$ merupakan kategori baik, $15,5 \leq$ skor $\leq 22,5$ merupakan kategori cukup, dan $9 \leq$ skor $\leq 15,5$ merupakan kategori kurang.

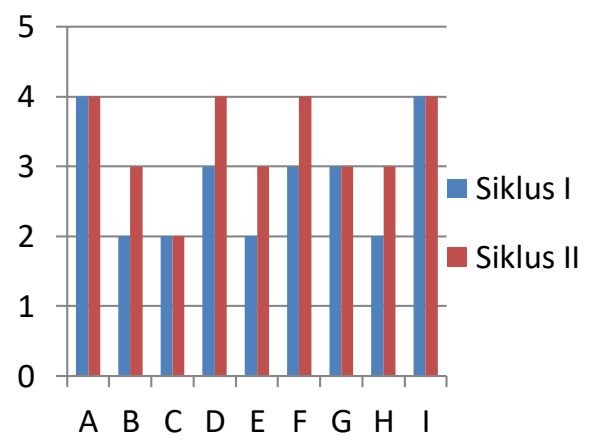

Gambar 1. Diagram Peningkatan Aktivitas Guru

Keterangan:

A. Penyiapan materi ajar oleh guru

B. Pembelajaran dimulai oleh guru

C. Kemampuan guru dalam penyampaian materi

D. Pengajuan masalah dengan penyelesaian menggunakan model pembelajaran $N H T$ dan pendekatan matematika realistik

E. Penjelasan mengenai jalannya diskusi kelompok dalam permainan menggunakan media kartu soal

F. Penjelasan kepada siswa mengenai penyajian hasil diskusi dalam pemecahan masalah

G. Penyampaian pertanyaan kepada siswa

H. Penjelasan materi kembali sebagai penguatan

I. Tindak lanjut dan motivasi untuk mengakhiri

proses pembelajaran.

Hasil observasi aktivitas siswa pada pembelajaran matematika menggunakan perpaduan model pembelajaran NHT dan pendekatan matematika realistik secara lebih jelas dapat dilihat pada Tabel 2 di bawah ini.

Tabel 2. Peningkatan Aktivitas Siswa

\begin{tabular}{l|c|c}
\hline \multicolumn{1}{c|}{ Indikator } & \multicolumn{2}{c}{$\begin{array}{c}\text { Perolehan } \\
\text { rata-rata skor }\end{array}$} \\
\cline { 2 - 3 } $\begin{array}{l}\text { Kesiapan siswa mengikuti pelajaran dengan } \\
\text { menggunakan perpaduan model pembelajaran NHT dan } \\
\text { pendekatan matematika realistik }\end{array}$ & 2,5 & 3,3 \\
\hline $\begin{array}{l}\text { Siswa mengemukakan pendapat yang berkaitan dengan } \\
\text { pemecahan masalah }\end{array}$ & 2 & 2,3 \\
\hline $\begin{array}{l}\text { Siswa bekerja dalam kelompok untuk menyelesaikan } \\
\text { masalah }\end{array}$ & 2,7 & 3 \\
\hline Siswa melaksanakan permainan dengan media kartu soal & 3,2 & 3,3 \\
\hline Siswa menyajikan hasil kerja dari proses pemecahan & 2,3 & 2,6 \\
\hline
\end{tabular}




\begin{tabular}{l|c|c}
\hline masalah yang telah dilakukan & & \\
\hline Siswa mengerjakan soal evaluasi & 3 & 3,5 \\
\hline Jumlah skor rata-rata & 15,7 & 18,1 \\
\hline Kategori & Baik & Baik \\
\hline
\end{tabular}

Klasifikasi kategori nilai klasikal untuk lembar pengamatan aktivitas siswa yaitu perolehan $20 \leq$ skor $\leq 24$ merupakan kategori sangat baik, $15 \leq$ skor $\leq 20$ merupakan kategori baik, 15 $\leq$ skor $\leq 20$ merupakan kategori baik, $10 \leq$ skor $\leq 15$ merupakan kategori cukup, dan $6 \leq$ skor $<10$ merupakan kategori kurang.

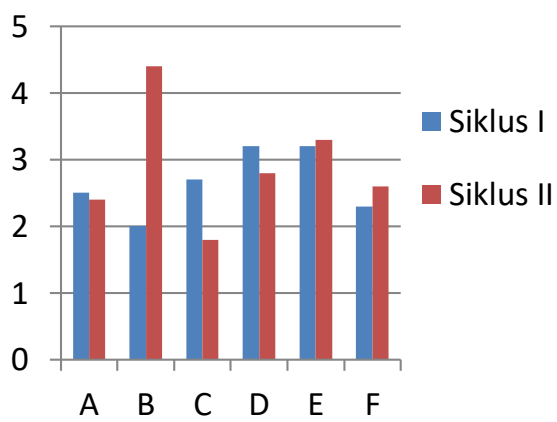

\section{Gambar 2. Diagram Batang} Peningkatan Aktivitas Siswa

Keterangan:

A. Kesiapan siswa mengikuti pelajaran dengan menggunakan perpaduan model pembelajaran NHT dan pendekatan matematika realistik
B. Siswa mengemukakan pendapat yang berkaitan dengan pemecahan masalah

C. Siswa bekerja dalam kelompok untuk menyelesaikan masalah

D. Siswa melaksanakan permainan dengan media kartu soal

E. Siswa menyajikan hasil kerja dari proses pemecahan masalah yang telah dilakukan

F. Siswa mengerjakan soal evaluasi.

Berdasarkan Tabel 2 dan Gambar 2 terlihat bahwa hasil observasi aktivitas siswa pada pembelajaran matematika dengan menggunakan perpaduan model pembelajaran NHT dan pendekatan matematika realistik dari siklus I ke siklus II mengalami peningkatan.

Selanjutnya, hasil observasi iklim pembelajaran pada pembelajaran matematika dengan perpaduan model pembelajaran NHT dan pendekatan matematika realistik dapat dilihat pada Error! Reference source not found. berikut.

Tabel 3. Peningkatan Kualitas Iklim Pembelajaran

\begin{tabular}{l|c|c}
\hline \multicolumn{1}{c|}{ Indikator } & \multicolumn{2}{c}{ Perolehan Skor } \\
\cline { 2 - 3 } & Siklus I & Siklus II \\
\hline Suasana kelas & 4 & 4 \\
\hline Interaksi dalam pembelajaran & 3 & 4 \\
\hline
\end{tabular}




\begin{tabular}{l|c|c}
\hline Total Perolehan & 7 & 8 \\
\hline Kategori & Sangat Baik & Sangat Baik \\
\hline
\end{tabular}

Klasifikasi kategori nilai klasikal untuk lembar pengamatan iklim pembelajaran yaitu kriteria ketuntasan $7 \leq$ skor $\leq 8$ merupakan kategori sangat baik, $5 \leq$ skor $<7$ merupakan kategori baik, $2 \leq$ skor $<3$ merupakan kategori kurang.

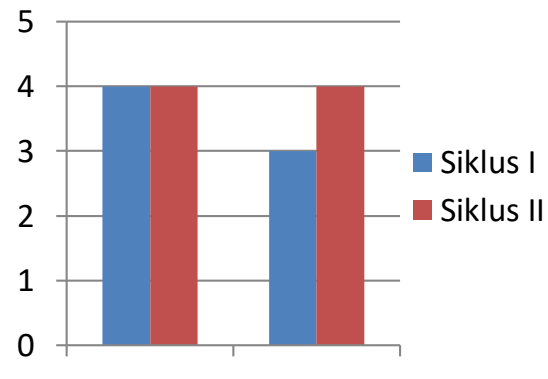

A B

\section{Gambar 3. Diagram Peningkatan} Iklim Pembelajaran

Keterangan:

A. Suasana kelas
B. Interaksi dalam pembelajaran

Berdasarkan Error! Reference source not found. dan Gambar 3 terlihat bahwa hasil observasi iklim pembelajaran dengan perpaduan model pembelajaran NHT dan pendekatan matematika realistik dari siklus I ke siklus II mengalami peningkatan.

Peningkatan hasil belajar siswa pada pembelajaran matematika menggunakan perpaduan model pembelajaran NHT dan pendekatan matematika realistik dari siklus I dan siklus II mengalami peningkatan. Secara lebih jelas, peningkatan tersebut dapat dilihat pada tabel di bawah ini.

Tabel 4. Tabel Peningkatan Hasil Belajar Siswa

\begin{tabular}{l|c|c|c}
\hline \multirow{2}{*}{ Pencapaian } & Data Awal & \multicolumn{2}{c}{ Data } \\
\cline { 3 - 4 } & & Siklus I & Siklus II \\
\hline Rata-rata & 54,65 & 66 & 75,52 \\
\hline Nilai terendah & 15 & 24 & 46 \\
\hline Nilai tertinggi & 95 & 100 & 100 \\
\hline Belum tuntas & $65,5 \%$ & $24,14 \%$ & $6,9 \%$ \\
\hline Tuntas & $34,5 \%$ & $75,86 \%$ & $93,1 \%$ \\
\hline
\end{tabular}

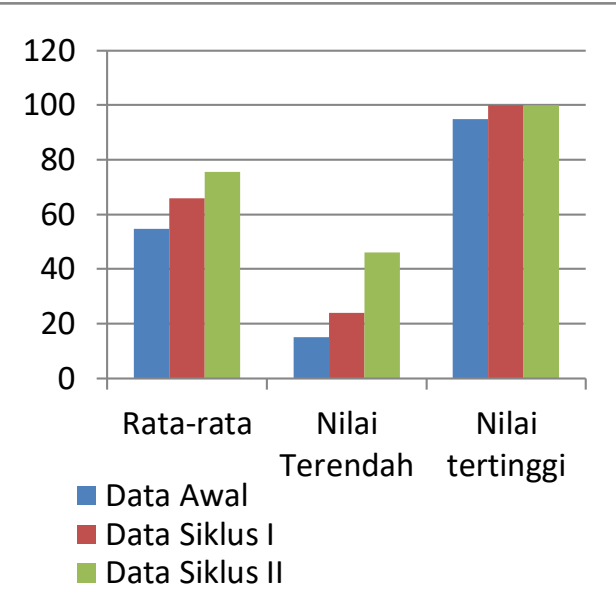




\section{Gambar 4. Diagram Peningkatan Hasil Belajar Siswa}

Berdasarkan hasil penelitian bahwa terdapat efektivitas peningkatan hasil belajar matematika dengan perpaduan model pembelajaran NHT dan pendekatan matematika realistik dari siklus I ke siklus II. Hasil belajar siklus I nilai rata-ratanya adalah 66 . Sedangkan ketuntasan belajar klasikal yang diperoleh siswa adalah 75,86\% dengan jumlah siswa sebanyak 29 siswa. Untuk siklus II nilai rata-rata hasil belajar adalah 75,52. Adapun ketuntasan belajar klasikal yang diperoleh adalah $93,1 \%$ dengan jumlah siswa sebanyak 29 siswa.

Menurut data di atas pada Error! Reference source not found. terdapat kenaikan hasil belajar serta kenaikan ketuntasan belajar klasikal dari siklus I ke siklus II, dari $75,86 \%$ menjadi $93,1 \%$. Terjadinya kenaikan hasil belajar dikarenakan dalam tahap pembelajaran guru melakukan kegiatan secara terencana dan sistematis.

Berdasarkan indikator keberhasilan yang ditetapkan, kriteria ideal ketuntasan klasikal adalah $80 \%$. Dari Error! Reference source not found. terlihat bahwa nilai belajar siswa pada siklus I menunjukkan bahwa presentase ketuntasan belajar klasikal siswa belum mencapai $80 \%$. Dengan demikian, penelitian dilanjutkan ke siklus II.

Setelah dilaksanakan siklus II ternyata diperoleh bahwa presentase ketuntasan siswa pada siklus II mencapai $93,1 \%$ dengan jumlah anak yang tuntas belajar sebanyak 26 dari 29 siswa. Dengan demikian, berdasarkan nilai kemampuan pemecahan masalah maka penelitian ini berhenti sampai di siklus II.

\section{SIMPULAN}

Dalam penelitian yang telah dilakukan terlihat adanya efektivitas peningkatan baik itu berupa keterampilan guru, aktivitas siswa, kualitas iklim pembelajaran, dan hasil belajar siswa dalam pembelajaran. Hal ini dapat membuktikan bahwa perpaduan model pembelajaran NHT dan pendekatan matematika realistik efektif untuk diterapkan dalam pembelajaran matematika pada guru dan siswa di tingkat sekolah dasar.

Berkenaan dengan hasil penelitian yang diperoleh maka peneliti memberikan saran kepada SD Negeri 
Kiarajangkung agar dapat menambah wawasan dan pengetahuan bagi para guru tentang berbagai jenis model kooperatif dan metode mengajar yang dapat digunakan dalam kegiatan pembelajaran yang efektif dan menyenangkan sehingga terjadi interaksi dengan siswa, pemahaman akademik dan peningkatan hasil belajar siswa. Selain itu, hasil penelitian ini dapat dijadikan acuan dan bahan perbandingan untuk penelitian selanjutnya. Bagi peneliti lain, peneliti memberikan saran untuk penelitian selanjutnya dapat menggunakan model kooperatif yang lain, seperti Student Teams Achievement Devisions (STAD), Team Game Tournament (TGT), Snowball Throwing, dan Group Investigation (Gl).

\section{DAFTAR PUSTAKA}

Arikunto. (2010). Penelitian Tindakan Kelas. Jakarta: Bumi Aksara.

Depdiknas. (2007). SKKD Tingkat SD/MI. Jakarta: Depdiknas.

Fathurrohman, Muhammad. (2015). Model-model Pembelajaran Inovatif. Yogyakarta: Ar-Ruzz Media.

Hadi, S. (2005). Pendidikan Matematika Realistik dan Implementasinya. Banjarmasin: Tulip.

Imtihanudin. 2021. "Students'Attitude In Learning Islamic Education
Course Trough Values Character Habituation" dalam Jurnal Cakrawala Pedagogik, Volume 5, Nomor 1.

Jannah, R. (2013). "Eksperimentasi Model Pembelajaran Kooperatif Tipe Structured Number Heads $(\mathrm{SNH})$ dan Numbered Heads Together (NHT) dengan Pendekatan Matematika Realistik pada Prestasi Belajar Matematika Ditinjau dari Kemandirian Belajar Siswa Kelas VII SMP Negeri di Kota Mataram Tahun Pelajaran 2012/2013." Tesis, Program Pascasarjana Universitas Negeri Surakarta.

Linda. (2020). "Upaya Meningkatan Hasil Belajar Mahasiswa PGMI Semester III STAI Syekh Manshur Pada Mata Kuliah Matematika II Melalui Model Pembelajaran Kooperatif Tipe Two Stay Two Stray (TSTS)" dalam Jurnal Cakrawala Pedagogik, Volume 4, Nomor 1.

Shoimin, A. (2014). 68 Model Pembelajaran Inovatif dalam Kurikulum 2013. Yogyakarta: ArRuzz Media.

Suratmin. (2020). "Penerapan Model Pembelajaran Student Teams Achievement Division (STAD) Untuk Meningkatkan Prestasi Siswa Belajar Bahasa Inggris" 
dalam Jurnal Dikdas Bantara, Volume 3.

Uno, H. B. (2012). Teori Motivasi dan Pengukurannya. Jakarta: Bumi Aksara.

Windayana, H. et al. (2007). Geometri dan Pengukuran. Bandung: UPI Press. 